\title{
A striated, far travelled clast of rhyolitic tuff from Thames river deposits at Ardleigh, Essex, England: evidence for early Middle Pleistocene glaciation in the Thames catchment
}

\author{
J. Rose ${ }^{1,2,{ }^{*}}$, J.N. Carney ${ }^{2}$, B.N. Silva ${ }^{1} \&$ S.J. Booth ${ }^{2}$ \\ 1 Department of Geography, Royal Holloway University of London, Egham, Surrey, TW20 0EX, UK. \\ 2 British Geological Survey, Keyworth, Nottingham, NG12 5GG, UK. \\ * Corresponding author. Email: j.rose@rhul.ac.uk and jrose@dircon.co.uk.
}

Manuscript received: February 2010, accepted: May 2010

\begin{abstract}
This paper reports the discovery of an in-situ striated, far-travelled, oversized clast in the Ardleigh Gravels of the Kesgrave Sands and Gravels of the River Thames at Ardleigh, east of Colchester in Essex, eastern England. The morphology, petrography and geochemistry of the clast, and the sedimentology of the host deposit are described. The striations are interpreted, on the basis of their sub-parallelism and the shape and subroundedness of the clast, as glacial and the clast is provenanced to Ordovician rocks of the Llŷn and Snowdonia regions of North Wales. On the basis of clast frequency within the Colchester Formation gravels of the Kesgrave Sands and Gravels it is inferred that glaciers reached the Cotswold region of the Thames catchment. Floe-ice transport during spring flood is invoked for movement from the glaciated region to eastern England. The paper discusses the possible age of the glaciation and recognises that it is difficult to be more precise than a cold stage in the early Middle Pleistocene (MIS 18, 16 or 14). Attention is drawn to the possibility of glaciation associated with a diamicton in the region of the Cotswold Hills known as the Bruern Till, but stresses the need for new work on this deposit.
\end{abstract}

Keywords: Early Middle Pleistocene (MIS 18-14) glaciation, Welsh sourced glaciation, oversized far-travelled clast, Ordovician rhyolitic vitric tuff, floe-ice transport

\section{Introduction}

Attempts to understand the glacial history of Britain have generated much work and much debate (see Clark et al., 2004 and Rose, 2009 for outlines of the current debates), and one of the issues of contention is the status of glacial events before MIS 12 (the Anglian Glaciation of the British Quaternary). Conventional views, as expressed in Bowen et al. (1999) and by Gibbard in Clark et al. (2004), find no evidence of substance for glaciation prior to MIS 12, whereas Whiteman and Rose (1992), Hamblin et al., (2000, 2005), Lee et al., (2004), Rose in Clark et al. (2004) and Rose (2009) identify much evidence for glaciations prior to MIS 12, proposing glaciations in Wales, a glaciation in the upper part of the present Thames catchment and lowland glaciation in eastern England. This issue is important as glaciation is perhaps the most effective indicator of how the climate of the British Isles responded to the climate forcing of the Early and early Middle Pleistocene, and in particular how Earth surface systems responded to obliquity-driven climate change and the Mid-Bruhnes Transition (Clark et al., 2006; Rose, 2010).

The critical problems fuelling this debate are the quality of the evidence used to propose glaciation, and the reliability of the evidence used to date the proposals. For instance, the Happisburgh Glaciation, which is well represented by unequivocal glacial deposits (the Happisburgh and Corton Tills) (Lee et al., 2004; Hamblin et al., 2005; Rose, 2009), is ascribed to MIS 16 on the basis of stratigraphic sequences and relationships with pre-MIS 12 Bytham river deposits, but this age is challenged by First Appearance Datum / Last Appearance Datum (FAD/LAD) biostratigraphy and AAR results, which suggest that such an early age is not possible (Preece et al., 2009). Likewise, a number of glaciations have been proposed for western Britain on the basis of glacially-sourced material (clasts provenanced to the Welsh Mountains and Borderlands) (Hey and Brenchley, 1977; 
Whiteman, 1990), and glacially fractured sand grains (Hey et al., 1971, Hey, 1976) in the Early and early Middle Pleistocene deposits of the River Thames. In this case, unlike the case for the Happisburgh Glaciation, the early age of the evidence is not in question, rather the issue is whether the evidence is good enough to justify the case for glaciation. It is possible, for instance, that the clasts could have been derived from the headwaters of the ancestral Thames catchment by frost shattering and transported from these regions by fluvial and ice-floe processes, and the origin of surface textures on sand grains remains an issue of debate (Whalley, 1996). Hey and Brenchley (1977, p. 224) noted that 'no glacial striae have yet been recognised on any pebbles of boulders of the Kesgrave gravels ...'.

This paper examines evidence for glaciation in the Thames catchment prior to MIS 12. It records the find of an in-situ, oversized clast from pre-diversion Thames river gravels in Essex, east of London (Fig. 1), which has surface ornamentation characteristic of glacial striations (Fig. 2A). The clast has a geochemical signature by which its provenance can be determined, and the location of the clast in an aggradation/terrace of the proto River Thames, provides a method by which the deposition of the clast may be dated. This paper therefore examines these properties and considers them within the schemes for a glacial history of Britain. The age of the glaciation is very difficult to resolve and all that can be said with confidence is that glaciation occurred in a cold stage of the early Middle Pleistocene (MIS 18-14) prior to MIS 12. Attention is drawn to possible evidence for glacier ice in the upper part of the present Thames catchment (Cotswold Hills) prior to MIS 12.

\section{Description, sedimentology and stratigraphic context}

\section{The clast}

The clast was found in the Kesgrave Sands and Gravels (KSG) (Rose et al., 1976, 1999; Bridgland, 1994), the pre-diversion deposits of the river Thames, at Martell's Sand and Gravel Pit,

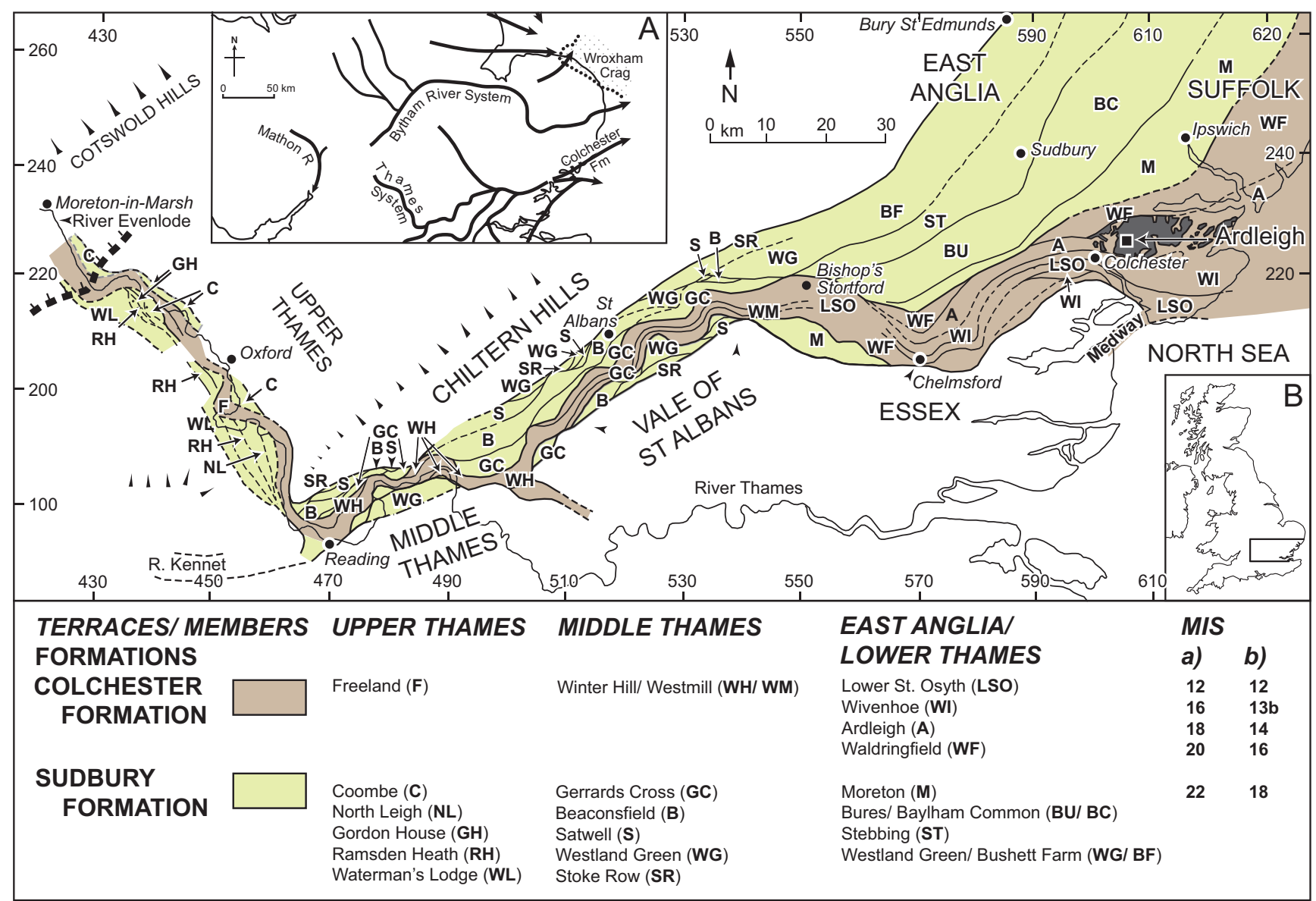

Fig. 1. Location of Ardleigh and the aggradations of the river Thames. The location of the terrace/aggradations of the pre-diversion River Thames is taken from Whiteman and Rose (1992, p. 365; Fig. 2). The individual terraces are named with a letter code related to a key in the lower part of the figure. The full names of the terraces are taken from Whiteman and Rose (1992, p. 369; Table 2). The location of the Ardleigh Gravels is shown in dark grey and the extent is taken from Bridgland (1994, p. 292; Fig. 5.4C). The location of the region is shown in Inset $B$ and the relation of the terrace system to the river pattern at the time of formation of the Ardleigh Gravels is shown in Inset $A$. The age of the aggradation/terraces is shown in terms of Marine Isotope Stage (MIS). Two sets of ages are given: a) is according to Westaway et al. (2002, p. 567; Fig. 5); b) is according to Westaway (2009, p. 262; Fig. 1). A possible limit for glaciation associated with deposits at Bruern is shown by a thick, dashed line at the western side of the area. 

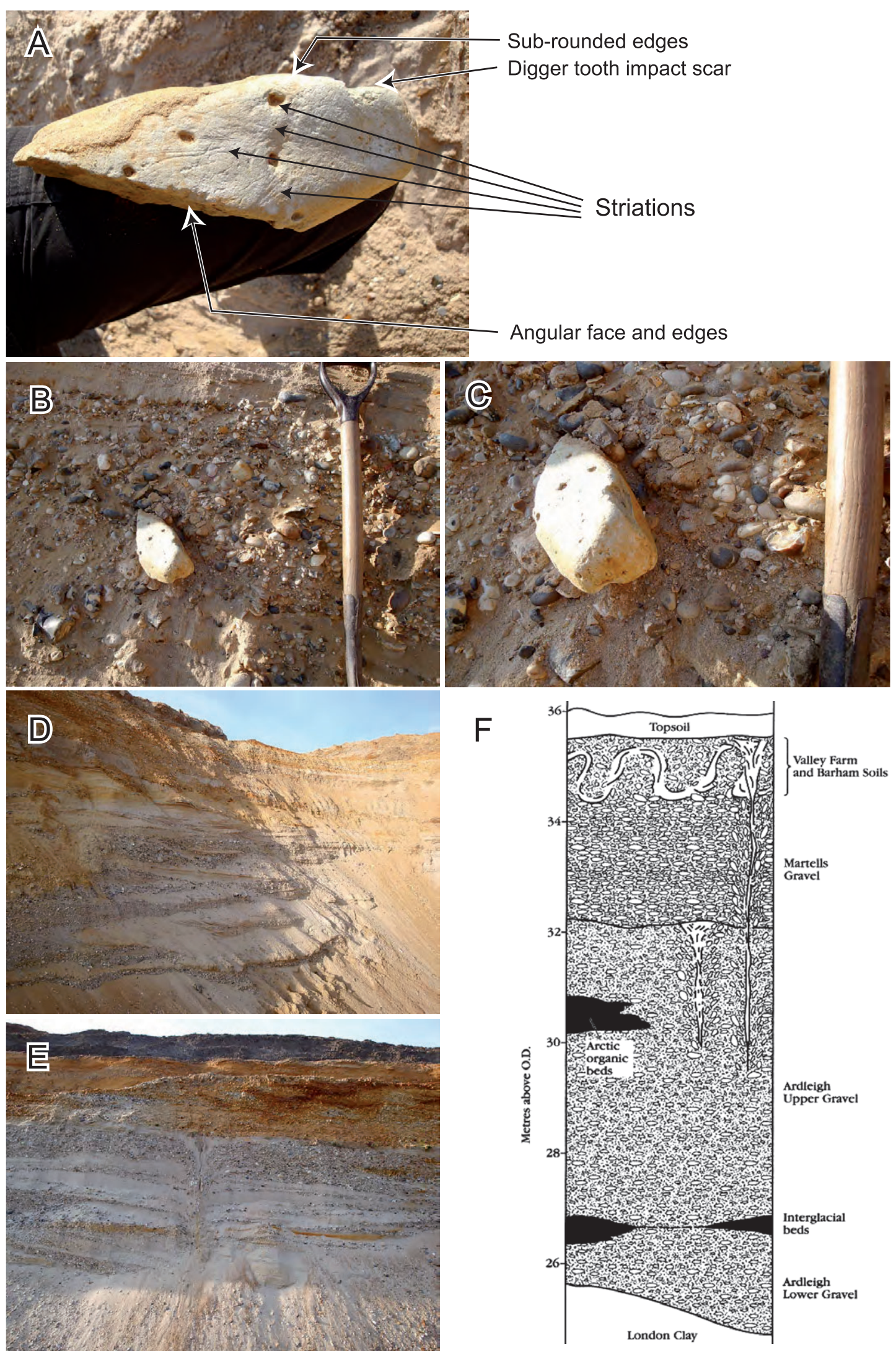

Fig. 2. Photographs of the find, the sedimentary structures and the composite stratigraphy at Ardleigh. A. The clast showing the surface ornamentation; $B$ and $C$. The clast in-situ before removal for examination; $D$. Sedimentary structures at the find site showing the lighter coloured Ardleigh Gravels in the lower part of the section and the more oxidized Martells Gravels in the upper part; E. An ice-wedge cast in the Ardleigh Gravels; F. A generalized stratigraphy for the Ardleigh area giving the names of the sedimentary units and palaeosols (taken from Bridgland, 1994, Fig. 5.9, p. 301). 
Ardleigh, near Colchester in Essex (National Grid Reference TM 054 279) (Fig. 1) on $20^{\text {th }}$ March 2009. The clast is an oblong block with dimensions $23 \times 8 \times 7 \mathrm{~cm}$ (Fig. 2A) and a pale grey to greenish grey colour, with some localised brown staining. Most of the edges of the block are sub-rounded, but one side and associated edges are angular. At one end there is a small indentation with very angular edges and a deeper green colour (Figs 2A, B, C) which is interpreted as an impact-scar from an excavator tooth while the block was held in the sands and gravels. There is no indication that the block has been disturbed since deposition until it was removed by two of the authors and taken to the laboratory for analysis. One surface of the block shows sub-parallel scratches cut into the surface, indicating localised abrasion by harder materials (Fig. 2A). These scratches are roughly parallel with the long-axis of the block and have the appearance of glacial striations typical of abrasion of one particle upon another during subglacial transport (Menzies and Shilts, 1996).

Clearly the origin of these scratches is critical to this study. Scratches on a clast can only be formed when a harder material is impressed on a softer material, and the two materials are held against one another. Processes by which scratches can form are subglacial, floe-ice transport and mass-flow such as gelifluction and landslipping. Striations formed on clasts in a subglacial environment are typically parallel because the particles are held in ice or till and a glacier adopts a generally uniform, gravity or inertia-driven direction, although particles can be rotated giving variety. Striations on clasts transported by river floe-ice are likely to be variable as the ice-floe will rotate as it moves downstream and clasts held within it impact on harder rock. Clasts in gelifluctate and landslip deposits have the potential to be parallel, but are more likely to show a range of directions because of flow and rotation of the sediment during movement and, for the same reason are also likely to be on all facets of the clast (Menzies and Shilts, 1996). In this case, the predominantly uniform direction of the striations on the clast from Ardleigh suggests a glacial origin. The edge-rounding and the fractured clast end are also typical of subglacial processes, although edge abrasion would also occur during mass-flow.

The in-situ block was so conspicuous, because of its anomalously large size, that it was photographed as an example of a mega-erratic from the KSG before being studied in detail (Figs 2A, B, C). After closer observation, and the identification of the scratches it was photographed further to show its alignment and relationship to the host material. The position of the digger-impact scar most likely indicates the position of the section face when the sands and gravels were last excavated. The position of the face at the time of observation shown in Figures $2 \mathrm{~B}$ and $\mathrm{C}$ indicates about $10-15 \mathrm{~cm}$ of granular collapse since excavation. The striations are within the $10-15 \mathrm{~cm}$ between the excavator impact scar and the present section face, meaning that there is no possibility that they could have been formed by anthropogenic processes during excavation.
The sedimentology and stratigraphy of the section were recorded and the clast was removed and photographed (Fig. 2A). The clast was taken to the laboratory at RHUL where it was subsequently examined, and then to the geochemical laboratories at the BGS where it was sampled for geochemistry in order to determine the provenance. The site at Ardleigh was re-visited on December $29^{\text {th }} 2009$ and the beds from which the clast was obtained were studied for palaeocurrent directional indicators. Samples were taken for clast lithological analysis in order that they could be compared with the published work of Bridgland (1994) and placed in their stratigraphic and palaeoenvironmental context.

\section{Sedimentology}

The deposits in which the clast was located are cross- and horizontally-bedded sands and sands and gravels (Fig. 2D, E) with a predominant orientation and dip of the cross-bed face of between $355^{\circ}$ and $10^{\circ}$ and $065^{\circ}$ and $12^{\circ}$ (six measurements), typical of bar deposition by a braided river with a predominant flow towards the NNE. Channel structures are relatively infrequent and where they do exist they are of small depth, usually less than $50 \mathrm{~cm}$, suggesting minimal reworking, shallow water depths and predominant deposition and aggradation. Ice-wedge casts were observed at a number of locations in the section (Fig. 2E) with lengths ranging from $>3.4 \mathrm{~m}$ to c. $50 \mathrm{~cm}$. There is no evidence that the ice-wedge casts are related to a single surface, in which case they would represent a longexposed land surface; rather, they are randomly scattered within the section reflecting relatively short periods in which individual bars were exposed and permafrost-driven thermal contraction extended into the ground (French, 1996).

The sands and gravels containing the clast are therefore interpreted as the deposits of a shallow, braided river flowing towards the NNE in a permafrost climate. Reworking of the sediments is minimal and aggradation is predominant. The existence of a number of ice-wedge casts indicates that bar surfaces remained above the flood level for several years meaning that the channel was highly unstable and shifted its main track at frequent intervals. The width of sands and gravels attributed to this lithological unit is about $10 \mathrm{~km}$ (Bridgland 1994) (Fig. 1), and it is likely that this is the width of the braidplain across which the seasonally-variable discharge oscillated, with different sections being drained during different floods.

The clast under consideration is anomalously large with no evidence of fluvial abrasion, and is typical of oversize clasts found at a number of localities in the KSG (Hey, 1976; Hey and Brenchley, 1977) and in the early Middle Pleistocene Rhine of continental Europe (Gibbard, 1988). It is therefore interpreted as a clast that has been frozen-into and transported by an icefloe (Martini et al., 1993). The fact that the fine ornamentation survives on the surface of the clast means that it has not suffered 
transport and abrasion since being deposited and that after deposition it was rapidly buried and protected by the overlying sediment. The presence of the oversize clast is therefore in accordance with the other evidence for cold climate fluvial sedimentation, ephemeral flood flows and rapid sedimentation.

\section{Stratigraphy}

Martells Quarry, Ardleigh is the type site for the Ardleigh Gravels which form the second highest of the four aggradations that comprise the Colchester Formation / Kesgrave Low-level Group (Whiteman and Rose, 1992; Bridgland, 1994), and is the subject of a detailed site description in Bridgland (1994, p. 299-305) (Fig. 2F). The succession consists of the Ardleigh Gravels which are a complex sequence of cold-climate gravels with intervening temperate-climate and cold-climate organic deposits, and the overlying Martells Gravels which have a complex palaeosol at the surface (Fig. 2F). The sedimentary structures described in Bridgland (1994) are similar to those observed in this study. In order to test this correlation samples were taken for clast lithological analysis (CLA) from a location adjacent to the striated clast and from the upper part of the section and the results have been compared with the values given in Table 5.2 of Bridgland (1994) (Table 1). Bridgland highlights the critical properties of the deposits at Ardleigh as the frequencies of chattermarked (Tertiary) flint, vein quartz and quartzite,
Carboniferous, Greensand and Rhaxella cherts and a presence of acid igneous rocks. He notes that the Ardleigh and Martells Gravels are differentiated by the higher proportion of chattermarked (Tertiary) flints in the Ardleigh Gravels, and the persistent occurrence of Rhaxella Chert in the Martells Gravels. Comparison of the results obtained in this study with those from Bridgland (1994) shows consistent similarities, including the occurrence of acid igneous porphyries and tuffs in the sample adjacent to the striated clast, and the diagnostic criteria for the two gravel units. This suggests that the gravels hosting the striated clast are the Ardleigh Gravels deposited by the River Thames while the gravels in the upper part of the section, and not the subject of this study, are the Martells Gravels deposited by a tributary river system.

\section{Petrography, geochemistry and provenance of the clast}

\section{Petrography and geochemistry}

When viewed under the hand lens, broken surfaces of the striated block reveal a shadowy clastic texture which is caused by abundant, rimmed, circular grey areas averaging 0.5-3 mm in size. These may represent individual lapilli, or they may be a result of devitrification.

Table 1. The frequency of lithological types in the 32-16 mm and 16-8/16-11.2 mm fractions in the sand and gravels at Ardleigh. The reference assemblages for the 32-16 mm and 16-11.2 mm fractions are taken from Bridgland (1994, p. 288) and are indicated by *. $n=$ total number of clasts counted.

\begin{tabular}{|c|c|c|c|c|c|c|c|c|c|c|c|}
\hline \multirow{2}{*}{$\begin{array}{l}\text { Sample No } \\
\text { v values }\end{array}$} & \multirow[t]{2}{*}{$\mathbf{n}$} & \multicolumn{2}{|l|}{ Flint } & \multirow{2}{*}{$\begin{array}{l}\text { Green- } \\
\text { sand } \\
\text { chert }\end{array}$} & \multicolumn{6}{|c|}{ Far-travelled } & \multirow{2}{*}{$\begin{array}{l}\text { Tertiary } \\
\text { flint: other } \\
\text { flint ratio }\end{array}$} \\
\hline & & Tertiary & Total & & V qzt & $\begin{array}{l}\text { Qzite } \\
\text { chert }\end{array}$ & $\begin{array}{l}\text { Carb } \\
\text { chert }\end{array}$ & Rhax & Ign & Total & \\
\hline \multicolumn{12}{|c|}{ Martells Gravels - 32-16 mm size fraction } \\
\hline Ardleigh $3^{*}$ & 512 & 20.5 & 76.6 & 1.6 & 10.4 & 8.2 & 1.4 & 0.2 & 0.8 & 21.9 & 0.36 \\
\hline Ardleigh $4 C^{*}$ & 605 & 19.3 & 76.7 & 0.7 & 11.7 & 7.3 & 2.5 & 0.2 & 0.5 & 22.6 & 0.34 \\
\hline \multicolumn{12}{|c|}{ Ardleigh Gravels - 32-16 mm size fraction } \\
\hline Ardleigh $1^{*}$ & 590 & 26.8 & 75.6 & 0.7 & 11.9 & 7.5 & 0.8 & 0 & 1.5 & 23.6 & 0.55 \\
\hline Ardleigh $2^{*}$ & 615 & 23.7 & 80 & 1.3 & 9.3 & 5.4 & 2 & 0 & 0 & 17.7 & 0.42 \\
\hline Ardleigh 4B* & 447 & 29.3 & 75.4 & 1.3 & 9.8 & 9.4 & 1.1 & 0 & 1.1 & 23 & 0.64 \\
\hline Ardleigh $4 \mathrm{~A}^{*}$ & 553 & 33.3 & 72 & 0.4 & 11.4 & 13.9 & 1.1 & 0 & 0.9 & 27.5 & 0.86 \\
\hline \multicolumn{12}{|c|}{ This study - 32-16 mm size fraction } \\
\hline Upper part & 314 & 27.4 & 74.2 & 0 & 14 & 9.9 & 1.6 & 0 & 0.3 & 25.5 & 0.58 \\
\hline At striated clast & 376 & 30.6 & 69.7 & 0 & 16.7 & 12.8 & 0.8 & 0 & 0 & 30.3 & 0.82 \\
\hline \multicolumn{12}{|c|}{ Martells Gravels - 16-11.2 mm and $16-8 \mathrm{~mm}$ size fractions } \\
\hline Ardleigh $4 C^{*}$ & 596 & 26.2 & 72.5 & 1 & 14.3 & 7.6 & 2.7 & 0.3 & 1 & 21.8 & 0.57 \\
\hline \multicolumn{12}{|c|}{ Ardleigh Gravels - 16-11.2 $\mathrm{mm}$ and $16-8 \mathrm{~mm}$ size fractions } \\
\hline Ardleigh $1^{*}$ & 1008 & 27.1 & 72.3 & 1.3 & 15.4 & 7.3 & 2.2 & 0 & 0.2 & 25.9 & 0.6 \\
\hline Ardleigh $2^{*}$ & 1219 & 29 & 69.9 & 0.7 & 14.9 & 9.5 & 3 & 0 & 0.7 & 29.1 & 0.71 \\
\hline \multicolumn{12}{|c|}{ This study $-16-8 \mathrm{~mm}$ size fraction } \\
\hline Upper part & 853 & 22.5 & 64.7 & 0.7 & 20.8 & 10.8 & 1.6 & 0.4 & 0.8 & 34.4 & 0.53 \\
\hline At striated clast & 731 & 23.5 & 64.8 & 1.6 & 20.6 & 9.7 & 1.8 & 0.1 & 0.1 & 32.3 & 0.57 \\
\hline
\end{tabular}


The microphotograph (Fig. 3) shows that the rock is a finegrained vitric tuff, consisting of tightly packed shards of fineash size that have devitrified to microcrystalline quartz-feldspar mosaics. The other pyroclastic constituents are small and very sporadic, angular to euhedral crystal fragments of plagioclase feldspar and (very minor) quartz. Only one 'exotic' constituent was seen, a silt-size, rounded clast of microcrystalline quartz, possibly representing a fragment of silicified rock.

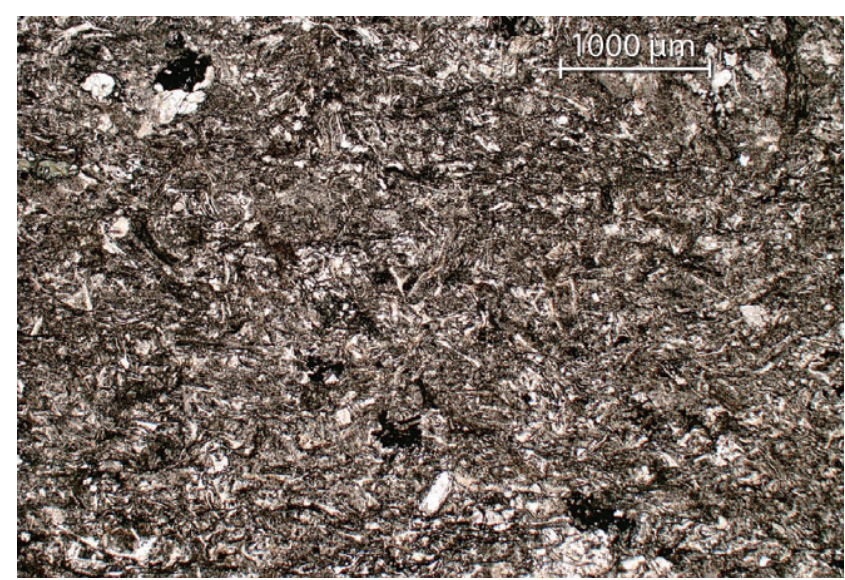

Fig 3. Photomicrograph of the Ardleigh rhyolitic tuff clast showing vitroclastic texture.

The larger and better-developed shards display sickle, crescentic, sliver and Y-shapes and for their most part are undeformed, suggesting that little if any welding took place after deposition. Some mild, localised sintering may, however, be indicated by laminae in which shards are slightly flattened. Minor variations in shard size between laminae suggest that sorting processes accompanied deposition of the ash. On the surface cut for the thin section, two sets of laminae are present, a parallel set containing the flattened shards and a second set, at an angle to the latter, which is more diffuse and in places is expressed as ellipsoidal areas. This second set may have been imposed after deposition, and is possibly a devitrification feature. There is no evidence for tectonic deformation, either in the thin section or hand specimen.

To determine the composition and geochemical affinities of this vitric-rich tuff, a sub-sample was analysed for a standard range of silicates and trace elements using the XRF facilities at BGS (Table 2). When adjusted for loss-on-ignition and plotted on a total alkalies/silica diagram the clast falls within the rhyolite field of Le Bas and Streckeisen (1991). Subalkaline verging to alkaline, mildly potassic affinities are indicated by the total alkalies content in relation to $\mathrm{Al}_{2} \mathrm{O}_{3}$, and a $\mathrm{K}_{2} \mathrm{O} / \mathrm{Na}_{2} \mathrm{O}$ ratio of 1.85 .

\section{Provenance of the clast}

The origin of volcanic pebbles in these deposits has long been the subject of speculation, but most workers now follow R.W. Sanderson (in Hey and Brenchley, 1977), who suggested
Table 2. Chemical composition of the Ardleigh tuff clast (XRF analysis at the BGS; selected trace elements are shown).

\begin{tabular}{lr}
\hline & wt.\% \\
\hline $\mathrm{SiO}_{2}$ & 72.95 \\
$\mathrm{TiO}_{2}$ & 0.31 \\
$\mathrm{Al}_{2} \mathrm{O}_{3}$ & 12.44 \\
$\mathrm{Fe}_{2} \mathrm{O}_{3}$ (tot) & 3.50 \\
$\mathrm{Mn}_{3} \mathrm{O}_{4}$ & 0.06 \\
$\mathrm{MgO}_{\mathrm{CaO}}$ & 0.85 \\
$\mathrm{Na}_{2} \mathrm{O}$ & 0.12 \\
$\mathrm{~K}_{2} \mathrm{O}$ & 2.59 \\
$\mathrm{P}_{2} \mathrm{O}_{5}$ & 4.79 \\
$\mathrm{ZrO}_{2}$ & 0.07 \\
$\mathrm{BaO}$ & 0.07 \\
$\mathrm{LOI}$ & 0.19 \\
\hline $\mathrm{Total}$ & 1.33 \\
\hline
\end{tabular}

\begin{tabular}{lrrrr}
\hline & ppm & & \multicolumn{2}{r}{ ppm } \\
\cline { 5 - 5 } $\mathrm{Sc}$ & 8 & & $\mathrm{Ba}$ & 1510 \\
$\mathrm{~V}$ & 16 & & $\mathrm{La}$ & 31 \\
$\mathrm{Cr}$ & 10 & & $\mathrm{Ce}$ & 75 \\
$\mathrm{Co}$ & 5 & & $\mathrm{Nd}$ & 46 \\
$\mathrm{Ni}$ & 16 & & $\mathrm{Sm}$ & 9 \\
$\mathrm{Zn}$ & 49 & & $\mathrm{Yb}$ & 10 \\
$\mathrm{Ga}$ & 19 & & $\mathrm{Hf}$ & 16 \\
$\mathrm{As}$ & 4 & & $\mathrm{Ta}$ & 2 \\
$\mathrm{Rb}$ & 105 & & $\mathrm{Th}$ & 19 \\
$\mathrm{Sr}$ & 120 & & $\mathrm{U}$ & 4 \\
$\mathrm{Y}$ & 85 & & \\
$\mathrm{Zr}$ & 484 & & \\
$\mathrm{Nb}$ & 31 & & \\
$\mathrm{Cs}$ & 3 & & & \\
\hline
\end{tabular}

on petrographical grounds that they were derived from the Ordovician volcanics of North Wales. There are, however, a number of possible source regions in southern Britain that could yield rhyolitic volcanic and tuff detritus, and as shown in Fig. 4 these include Ordovician and Neoproterozoic (late Precambrian) rocks. One means for discriminating between these various sources is to compare silicate and immobile trace element compositions of outcropping rocks with the Ardleigh clast. It is emphasized, however, that any conclusions drawn from a single sample must be regarded with caution, and that an exhaustive comparative geochemical appraisal of southern British volcanic rocks is beyond the scope of this study.

Rhyolitic lavas and tuffs are known to occur in the late Neoproterozoic successions of the Uriconian Volcanic Group of Shropshire (e.g. The Wrekin), and the Arfon Group and Pebidian Supergroup of Wales (Fig. 4). There is little published geochemical information available for these rocks; however, Thorpe (1972) gives a value of 643 ppm Zr for 8 averaged Uriconian rhyolites. Given that this is an average value, and taken together with figures quoted for other trace elements ( $\mathrm{Y}, \mathrm{La}, \mathrm{Ce}$ ), a comparison could be made with the Ardleigh clast. Against this, however, the averaged Uriconian rhyolite is noticeably less alkalies rich $\left(\mathrm{Na}_{2} \mathrm{O}+\mathrm{K}_{2} \mathrm{O}=7.0 \%\right)$ than the Ardleigh clast, and is considerably more sodic, with a $\mathrm{K}_{2} \mathrm{O} / \mathrm{Na}_{2} \mathrm{O}$ ratio of 0.5 . The Uriconian rocks, and for similar reasons rhyolites from the Warren House Group in the Malverns (Thorpe, 1972), are therefore unlikely to represent sources for the Ardleigh clast.

Mid-Ordovician (Caradoc) acid volcanics (i.e. $\mathrm{SiO}_{2}>70 \%$ ) of the Borrowdale and Eycott groups in the Lake District are dominantly potassic varieties but are unlikely sources because they generally have less than 455 ppm $\operatorname{Zr}$ (Millward et al., 2000; unpublished BGS data). This is lower than the Ardleigh clast, which therefore falls outside of the field of Lake District rocks 


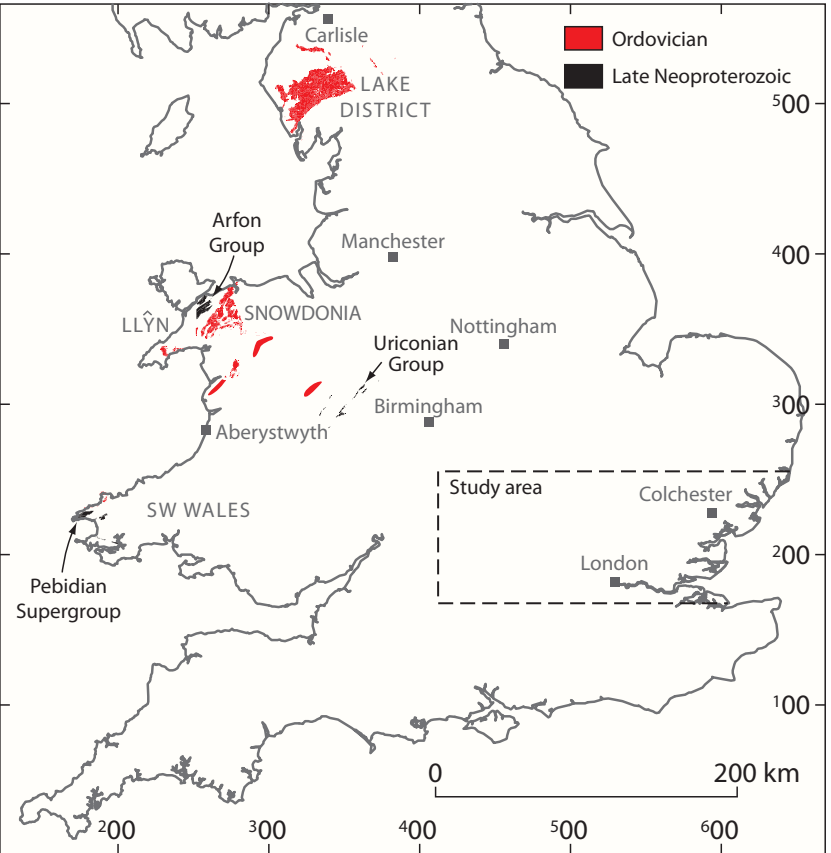

Fig. 4. Distribution of outcrops with rhyolitic pyroclastic rocks in relation to the study area shown in Fig. 1.

on plots using this trace element, as shown by the $\mathrm{Nb}$ vs $\mathrm{Zr}$ diagram (Fig. 5). A comprehensive comparative survey of other trace element abundances has not been attempted but it is noted, for example, that most Lake District volcanic rocks have $\mathrm{La} / \mathrm{Nb}$ ratios greater than the value of 1.0 for the Ardleigh clast.

The best geochemical match for the Ardleigh clast is provided by the mid-Ordovician (Caradoc) volcanic rocks of Wales, for which analytical data has been published for the outcrops in

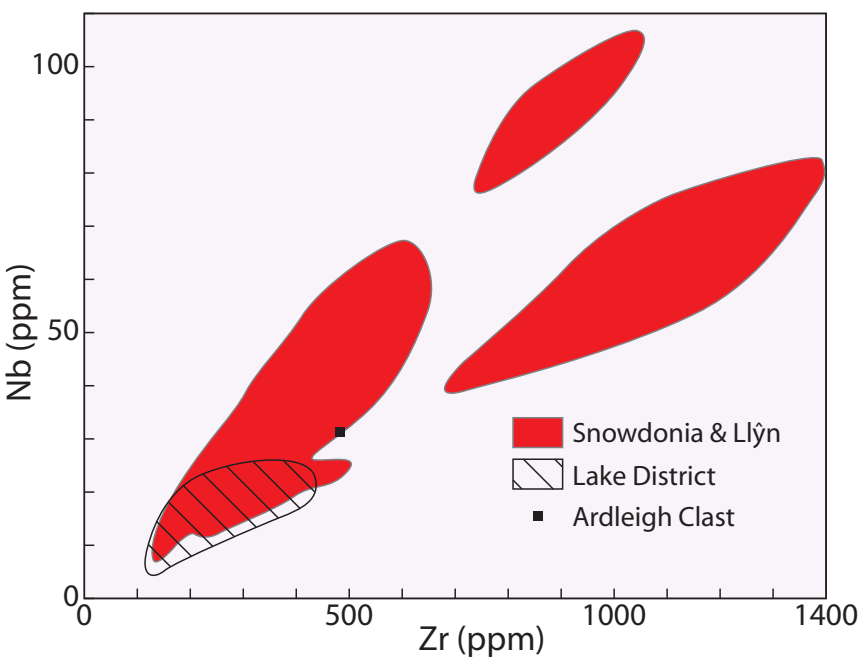

Fig. 5. Nb vs Zr plot comparing the Ardleigh tuff clast with Ordovician volcanic rocks in southern Britain. The field of Lake District rocks includes data from the Eycott Volcanic Group presented by Millward et al. (2000), and unpublished BGS analytical data for acid volcanic rocks of the Borrowdale Volcanic Group. The Welsh volcanic rocks are from the outcrops in Snowdonia (Thorpe et al., 1993) and Llŷn (Gibbons \& Young, 1999).
Snowdonia (Thorpe et al., 1993), Llŷn (Gibbons and Young, 1999) and SW Wales (Bevins et al., 1991). Snowdonia rhyolites studied by Thorpe et al. (1993) are considered to have subalkaline affinities, although for the Llŷn suites a wide variation in alkalies content was demonstrated by Gibbons and Young (1999). On immobile trace element variation diagrams, the Welsh volcanic rocks follow a number of separate crystallisation paths, as shown by the $\mathrm{Nb} / \mathrm{Zr}$ distributions in Fig. 5 . On this diagram, the Snowdonia and Llŷn rhyolites plot as a series of ellipsoidal clusters, one of which includes the Ardleigh clast ( $\mathrm{Nb} / \mathrm{Zr}=0.064)$; the $\mathrm{Nb} / Y$ ratio of 0.36 for the Ardleigh clast also compares with certain of the Llŷn and Snowdonia rhyolite groupings. When plotted on diagrams showing ratios and fractionation trends between $\mathrm{Nb} / \mathrm{Th}, \mathrm{Ta} / \mathrm{Zr}$ and $\mathrm{TiO}_{2} / \mathrm{Zr}$, the Ardleigh clast lies within the fields of Snowdonian rocks, with particular affinities to the subalkaline rhyolite groupings 'A2' and 'B2' of Thorpe et al. (1993).

\section{Discussion}

\section{The case for glaciation}

Accepting the Welsh or Welsh Borderland provenance of the tuff block from Ardleigh, the issue now is how it reached this locality. The surface ornamentation, which is interpreted as glacial striation, and the shape and roundedness of the block of tuff in the Ardleigh Gravels form the case for glaciation. Supplementary support for glaciation in the Ardleigh Gravels is provided by the increased frequency of far-travelled igneous clasts within Ardleigh deposit, relative to the frequency in the deposits of the earlier Sudbury Formation (Whiteman, 1992; Whiteman \& Rose, 1992; Rose et al., 1999). This argument is based on the interpretation that the deposits of the Sudbury Formation were linked directly to Wales and the Welsh Borderland by an extended, integrated catchment of the River Thames (see Rose et al., 2001, Fig 2B, p. 8), whereas the deposits of the Colchester Formation, which includes the Ardleigh Gravels, were deposited by a river that drained a region similar to the present upper and middle Thames catchment. At this time the Thames catchment did not extend beyond the Cotswold Hills (Fig. 1A). This increase in the frequency of far-travelled igneous clasts in the Ardleigh Gravels has been attributed to a glaciation from Wales crossing the Cotswold Hills and transporting the material into the present Thames catchment (Whiteman and Rose, 1992; Rose et al., 1999). Only one other mechanism of increasing the frequency of far travelled material seems possible: that of increasing the relative frequency of a particular rock type by comminution and removal of softer rocks. However, this process cannot apply in this case, as the igneous tuffs and rhyolites (and some greywackes) are more erodible than the flints, vein quartz, quartzite and cherts that make up the remainder of the deposit and would indeed have decreased in frequency if this had been 
the process. Also the large size and angular shape and roundedness of many of the igneous rocks suggest new input rather than a frequency-change due to abrasion and comminution. Recognition of the increased frequency of far-travelled clasts is critical as it means reworking of existing deposits cannot be the source of the erratic material and that an additional input of this far travelled material is required. Thus a new glaciation is required to have reached the Thames catchment.

Following from the evidence of the increased frequency of igneous clasts within the Ardleigh Gravels, the case was made for linking this deposit to a diamicton on the Cotswold Hills that has been interpreted as glacial and is known as the Bruern Till (Hey, 1986, p. 294; Whiteman and Rose, 1992, p. 373). This deposit is worthy of further study using present-day techniques. Nevertheless, in the absence of such a study, it is suggested that the striated tuff clast at Ardleigh and the increase frequency of igneous clasts provide evidence for glaciation in the upper part of the Thames catchment during the period when the Ardleigh Gravels were deposited.

\section{The process of transport from the glacier margin to eastern England}

There is general acceptance that the angular, over-large material in river deposits is the product of transport by icefloes during floods (Martini et al., 1993). This process has two stages. In stage one the slower-moving parts of rivers freeze over and around clasts that reach towards or above the water surface. Large clasts are preferentially selected because they stand above the bed of the river and are nearer to the freezing water surface. In stage two a thaw sets-in, rivers flood and river-ice breaks-up into separate floes. These floes float at the river surface carrying with them the frozen-in clasts which are then transported downstream until the ice melts and the clasts are released and dropped into the channel to be scoured or buried by subsequent river activity. The process involves the production of striations on the base of the clasts, but in a random fashion associated with rotation of the ice-flow, and the production of impact scars where clasts in the moving icefloe make contact with obstructions. However, the process does not involve rolling and abrasion and clasts transported by this mechanism can maintain an inherited shape and roundedness. Thus this process has been envisaged for the origin of the angular, over-large material in the KSG. Further support for the process is the observation that clusters of fartravelled clasts have been observed at locations within the KSG, suggesting a locality where an ice-floe had grounded and proceeded to melt and release its frozen-in load.

This process occurs at glacier margins where material such as striated clasts can be released directly from the ice, or at any location where rivers are eroding glacial deposits that contain striated material. It is suggested that the striated clast from Ardleigh has been derived either from a glacier margin within the Cotswold region of the upper Thames catchment or from eroded till within the same region. It should be pointed out that the Ardleigh Gravels were deposited long before the glaciers reached the London area in MIS 12 (Anglian Glaciation) (Gibbard, 1977; Bridgland, 1994) and, further, igneous material provenanced to Wales has not been found in the Anglian age glacial deposits that could contribute to Thames river deposits (Allen et al., 1991).

\section{Dating the glaciation}

Attempting to date early Middle Pleistocene sediments is a major challenge for Quaternary science, especially in the absence of biological remains suitable for AAR (Penkman et al., 2008) or chronologically diagnostic stratigraphic remains (Preece and Parfitt, 2000, 2009). Palaeomagnetism is appropriate and the site at Ardleigh has been studied. The results have been published (Maher and Hallam, 2005) indicating normal polarity with the inference that the gravels are younger than $780 \mathrm{ka}$.

The association between the striated clast and fluvial deposits that are arranged in an aggradation/incision sequence may, however, provide a mechanism by which it is possible to estimate age, at least to the level of Marine Isotope Stage (MIS). This is based on the principle that: 1) aggradation takes place in cold stages in the lower part of large, integrated, cool-temperate latitude river systems, when physical processes dominate unvegetated terrain and stream power is high in the middle parts of the catchment; and 2) incision takes place in warmer stages when material is locked into a landscape that is covered by vegetation and stream power is low due to moderate discharges. In this case the work done is concentrated in the river channels (Rose, 2009). Provided the aggradations can be separated, then these processes provide a method by which it is possible to date the deposits constituting the aggradation. Separation of the aggradations is brought about in the middle parts of large, integrated river systems by erosion-driven uplift (Westaway et al., 2002; Leeder, 2008) which creates a 'staircase'. The amount of separation is proportional to the uplift, and although the Ardleigh area is in the lower part of the Thames drainage system, and the amount of uplift is less than in the Middle Thames (Bridgland, 1994, 2006), separation has been clearly defined (Bridgland \& Allen, 1996). These principles have been tested by Bridgland and Schreve $(2001,2004)$ using mammalian assemblage biostratigraphy and existing geochronometric ages. Thus there are five aggradations, separated by incisions, between MIS 12 and 2 (MIS12, 10, 8, 6, 4-2). Using this principle, and the recognition that the Ardleigh Gravels are in the second aggradation above that formed during MIS 12, then the Ardleigh Gravel containing the striated clast are of MIS 16 age, which is in the range 642 to $615 \mathrm{ka} \mathrm{BP}$ (Bassinot et al., 1994). However, the tentative nature of this age attribution is highlighted by the fact that a MIS 18 age was ascribed to the Ardleigh Gravels by Westaway et al. in 2002 (Fig. 5), but in 2009 the same author 
favoured a MIS 14 age (Westaway, 2009, Fig. 1) (Fig. 1). Although an MIS 16 age is favoured here, it is recommended that all that can be proposed with confidence at present is that the age of the glaciation that entered the Thames catchment and transported the striated erratic is early Middle Pleistocene (pre-MIS 12).

\section{Conclusions}

- A striated, over-sized clast has been observed in-situ in the Ardleigh Gravels of the Kesgrave Sands and Gravels of the River Thames at Ardleigh in Essex, east of Colchester.

- The striations are interpreted as formed by glaciation and provide evidence for glaciation in the Thames catchment in the region of the Cotswold Hills. This glaciation is associated with the Bruern Till, previously identified in the region.

- The clast is interpreted as having been transported to the Ardleigh region from the headwaters of the catchment in floe-ice, during periods of spring flooding.

- The striated over-sized clast is identified as a rhyolitic vitric tuff, and is provenanced on the basis of its geochemistry to the Ordovician rocks of this type in the Llŷn and Snowdonia regions of North Wales.

- The river aggradation that contains the striated clast is dated on the basis of a stream-power driven aggradation/incision model to MIS 16 (642-615 ka), an age which is in accord with a normal palaeomagnetic signal obtained at the site. However this age is not confirmed by age attributions derived by uplift modelling which ascribe the Ardleigh Gravels to either MIS 18 (Westaway et al., 2002) or MIS 14 (Westaway 2009).

- The Cotswold region of the present Thames Catchment was glaciated by ice from Wales during the early Middle Pleistocene (pre-MIS 12) and this ice transported erratic material that was subsequently reworked by meltwater or the river Thames and transported to Essex in eastern England.

\section{Acknowledgments}

Adrian Palmer is thanked for preparing the thin section. We would also like to thank the un-named individual and Kenneth Rijsdijk who reviewed the paper and provided many very perceptive comments that have been of great help. This paper is published with the permission of the Executive Director, BGS (NERC).

\section{References}

Allen, $\boldsymbol{P .}$. 1983. Middle Pleistocene stratigraphy and landform development in southeast Suffolk. Unpublished PhD Thesis, University of London, 506 pp.

Allen, P., Cheshire, D.A. \& Whiteman, C.A., 1991. The tills of southern East Anglia. In: Ehlers, J., Gibbard, P.L. \& Rose, J. (eds): Glacial Deposits in Great Britain and Ireland. Balkema (Rotterdam): 255-278.
Bassinot, F.C., Labeyrie, L.D., Vincent, V., Quidelleur, X., Shackleton, N.J. \& Lancelot, Y., 1994. The astronomical theory of climate and the age of the Brunhes-Matuyama magnetic reversal. Earth and Planetary Science Letters 126: 91-108.

Bevins, R.E., Lees, G.J. \& Roach, R.A., 1991. Ordovician bimodal volcanism in SW Wales: geochemical evidence for petrogenesis of the silicic rocks. Journal of the Geological Society (London) 148: 719-729.

Bowen, D.Q. (ed.), 1999. A revised correlation of Quaternary deposits in the British Isles. The Geological Society Special Report No 23 (London), 174 pp.

Bridgland, D.R., 1994. Quaternary of the Thames. Chapman and Hall (London), $441 \mathrm{pp}$.

Bridgland, D.R., 2006. The Middle and Upper Pleistocene sequence in the Lower Thames: a record of Milankovitch climatic fluctuation and early human occupation of southern Britian. Proceedings of the Geologists' Association 117: 281-305.

Bridgland, D.R. \& Allen, P., 1996. A revised model for terrace formation and its significance for the early Middle Pleistocene terrace aggradations of northeast Essex, England. In: Turner, C. (ed.): The Early Middle Pleistocene in Europe. Balkema (Rotterdam): 121-134.

Bridgland, D.R. \& Schreve, D.C., 2001. River terrace formation in synchrony with long-term climatic fluctuation: examples from SE England. In: Maddy, D., Macklin, M. \& Woodward, J. (eds): River Basin Sediment Systems: Archives of Environmental Change. Balkema (Rotterdam): 229-248.

Bridgland, D.R. \& Schreve, D.C., 2004. Quaternary lithostratigraphy and mammalian biostratigraphy of the Lower Thames terrace system, south-east England. Quaternaire 15: 29-40.

Clark, C.D., Gibbard, P.L. \& Rose, J., 2004. Pleistocene glacial limits in England, Scotland and Wales. In: Ehlers, J. \& Gibbard, P.L. (eds): Pleistocene Glacial Limits, Volume 1. Elsevier (Amsterdam): 47-82.

Clark, P.U., Archer, D., Pollard, D., Blum, J.D., Rial, J.A., Brovkin, V., Mix. A.C., Pisias, N.G. \& Roy, M., 2006. The Middle Pleistocene Transition: characteristics, mechanisms, and implications for long term changes in atmospheric $\mathrm{pCO}_{2}$. Quaternary Science Reviews: 3150-3184.

French, H.M., 1996. The Periglacial Environment (2 ${ }^{\text {nd }}$ Edition). Longman, Harlow.

Gibbard, P.L., 1977. Pleistocene history of the Vale of St. Albans. Philosophical Transactions of the Royal Society of London B280: 445-483.

Gibbard, P.L., 1988. The history of the great Northwest European rivers during the past three million years. Philosophical Transactions of the Royal Society of London B318: 559-602.

Gibbons, W. \& Young, T.P., 1999. Mid-Caradoc magmatism in central Llŷn, rhyolite petrogenesis and the evolution of the Snowdonia volcanic corridor in NW Wales. Journal of the Geological Society of London 156: 301-316.

Hamblin, R.J.O, Moorlock B.S.P. \& Rose, J., 2000. A New Glacial Stratigraphy for Eastern England. Quaternary Newsletter 92: 35-43.

Hamblin, R.J.O., Moorlock, B.S.P., Rose, J., Lee, J.R., Riding, J.B., Booth, S.J. \& Pawley, S.M., 2005. Revised pre-Devensian glacial stratigraphy in Norfolk, England. Netherlands Journal of Geosciences 84: 77-85.

Hey, R.W., 1976. Provenance of far travelled pebbles in the pre-Anglian Pleistocene of East Anglia. Proceedings of the Geologists' Association 87: 69-82.

Hey, R.W., 1986. A re-examination of the Northern Drift of Oxfordshire. Proceedings of the Geologists' Association 97: 291-301.

Hey, R.W. \& Brenchley, P.J., 1977. Volcanic pebbles from the Pleistocene gravels in Norfolk and Essex. Geological Magazine 114: 219-225. 
Hey, R.W., Krinsley, D.H. \& Hyde, P.J.W., 1971. Surface textures of sand grains from the Hertfordshire pebble beds. Geological Magazine 108: 377-382.

Le Bas, M.J. \& Streckeisen, A.L., 1991. The IUGS systematics of igneous rocks. Journal of the Geological Society 148: 825-833.

Lee, J.R., Rose, J., Hamblin, J.O. \& Moorlock, B.S.P., 2004. Dating the earliest lowland glaciation of eastern England: a pre-MIS 12 early Middle Pleistocene Happisburgh Glaciation. Quaternary Science Reviews 23: 1551-1566.

Leeder, M.R., 2008. Tectonics, surface uplift and river incision: general models, case histories and applications to East Anglia and southern England. Bulletin of the Geological Society of Norfolk 58: 3-36.

Maher, B.A. \& Hallam, D.F., 2005. Palaeomagnetic correlation and dating of Plio/ Pleistocene sediments at the southern margins of the North Sea Basin. Journal of Quaternary Science 20: 67-77.

Martini, I.P., Kwong, J.K. \& Sadura, S., 1993. Sediment ice rafting and cold climate fluvial deposits: Albany River, Ontario, Canada. Special Publication of the International Association of Sedimentologists 17: 63-76

Menzies, J. \& Shilts, W.W., 1996. Subglacial environments. In: Menzies, J. (ed.): Past Glacial Environments: Sediments, Forms and Techniques. ButterworthHeinemann (0xford): 15-136.

Millward, D., Marriner, G.F. \& Beddoe-Stephens, B., 2000. The Eycott Volcanic Group, an Ordovician continental margin andesite suite in the English Lake District. Proceedings of the Yorkshire Geological Society 53: 81-96.

Penkman, K.E.H., Kaufman, D.S., Maddy, D. \& Collins, M.J., 2008. Closed-system behaviour of the intra-crystalline fraction of amino acids in mollusc shells. Quaternary Geochronology 3: 2-25.

Preece, R.C. \& Parfitt, S.A., 2000. The Cromer Forest-bed Formation: new thoughts on an old problem. In: Lewis, S.G., Whiteman, C.A. \& Preece, R.C. (eds): The Quaternary of Norfolk and Suffolk, Field Guide. Quaternary Research Association (London): 29-34.

Preece, R.C. \& Parfitt, S.A., 2008. The Cromer Forest-bed Formation: some recent developments relating to early human occupation and lowland glaciation. In: Candy, I., Lee, J.R. \& Harrison, A.M. (eds): The Quaternary of northern East Anglia, Field Guide. Quaternary Research Association (London): 60-83.

Preece, R.C., Parfitt, S.A., Coope, G.R., Penkman, K.E.H., Ponel, P. \& Whittaker, J.E., 2009. Biostratigraphic and aminostratigraphic constraints on the age of the Middle Pleistocene glacial succession in north Norfolk, UK. Journal of Quaternary Science 24: 557-580.

Rose, J., 2009. Early and Middle Pleistocene landscapes of eastern England. Proceedings of the Geologists' Association 120: 3-33.

Rose, J., 2010. The Quaternary of the British Isles: factors forcing environmental change. Journal of Quaternary Science 25: 399-418.

Rose, J., Allen P. \& Hey, R.W., 1976. Middle Pleistocene stratigraphy in southern East Anglia. Nature, 263: 492-494.

Rose, J., Moorlock, B.S.P. \& Hamblin, R.J.O., 2001. Pre-Anglian fluvial and coastal deposits in Eastern England: lithostratigraphy and palaeoenvironments. Quaternary International 79: 5-22.

Rose, J., Whiteman, C.A., Allen, P. \& Kemp, R.A., 1999. The Kesgrave sands and gravels: 'pre-glacial' Quaternary deposits of the River Thames in East Anglia and the Thames Valley. Proceedings of the Geologists' Association 110: 93-116.

Thorpe, R.S., 1972. The geochemistry and correlation of the Warren House, the Uriconian and the Charnian volcanic rocks from the English Pre-cambrian. Proceedings of the Geologists' Association 83: 269-285.
Thorpe, R.S., Leat, P.T., Mann, A.C., Howells, M.F., Reedman, A.J. \& Campbell, S.D.G., 1993. Magmatic evolution of the Ordovician Snowdon Volcanic Centre, North Wales (UK). Journal of Petrology 34: 711-714.

Westaway, $R_{\text {., }}$ 2009. Quaternary vertical crustal motion and drainage evolution in East Anglia and adjoining parts of southern England: chronology of the Ingham River terrace deposits. Boreas 38: 261-284.

Westaway, R. Maddy, D. \& Bridgland, D., 2002. Flow in the lower continental crust as a mechanism for the Quaternary uplift of south-east England: constraints from the Thames terrace record. Quaternary Science Reviews 21: 559-603.

Whalley. W.B., 1996. Scanning electron microscopy. In: Menzies, J. (ed.): Past Glacial Environments: sediments forms and techniques. ButterworthHeinemann: 357-375.

Whiteman, C.A., 1990. Early and Middle Pleistocene stratigraphy in central Essex, England. Unpublished PhD Thesis, University of London.

Whiteman, C.A., 1992. The palaeogeography and correlation of pre-Anglian Glaciation terraces of the river Thames in Essex and the London Basin. Proceedings of the Geologists' Association 103: 37-56.

Whiteman, C.A. \& Rose, J., 1992. Thames river sediments of the British Early and Middle Pleistocene. Quaternary Science Reviews 11: 363-375. 